\title{
An Overview of Glass Ceiling, Tiara, Imposter, and Queen Bee Barrier Syndromes on Women in the Upper Echelons
}

\author{
Sabirah Ambri ${ }^{1}$, Lokman Mohd Tahir $^{2}$ \& Rose Alinda Alias ${ }^{2}$ \\ ${ }^{1}$ Department of Educational Foundation and Social Science, Faculty of Education, Universiti Teknologi \\ Malaysia, Johor, Malaysia \\ ${ }^{2}$ Department of Information System, Faculty of Computing, Universiti Teknologi Malaysia, Johor, Malaysia \\ Correspondence: Sabirah Ambri, Department of Educational Foundation and Social Science, Faculty of \\ Education, Universiti Teknologi Malaysia, Johor, Malaysia. E-mail: sabirah2@live.utm.my
}

Received: November 6, 2018

Accepted: December 1, 2018

Online Published: December 28, 2018

doi:10.5539/ass.v15n1p8

URL: https://doi.org/10.5539/ass.v15n1p8

\begin{abstract}
The increasing women participation in the upper management level has been a comprehensive research study for women and career studies. Although only a few of them have had successfully broken the glass ceiling, they still have to struggle to keep up with the opposite gender. The purpose of the research study is to review past research studies on the glass ceiling syndrome, tiara syndrome, imposter syndrome, and queen bee barrier syndromes that commonly occur in women's career progression and understand how it affects women's career success. This paper reports the results of a literature review on four barrier syndromes in 45 combinations of research paper, books, magazine, thesis and discussion paper. Women need to have skills and ability in order to be leaders of upper management. The result of the study could provide a better understanding of the barriers that effects the women leaders in becoming successful. Thus, this research is conducted to gather and review the literature on the barrier syndromes and how it affects women's success in their careers.
\end{abstract}

Keywords: glass ceiling, tiara, imposter, queen bee syndromes, women

\section{Introduction}

In the new global economy, women have historically become a central issue for lack of access to the power structures of organisations, where experience has told them that connections to this power structure and the decision makers would enhance their position in organisations (Ilhaamie et al., 2014). In a study conducted by Azmi et al. (2012) has shown that the majority of women population have felt the need for women's contribution to the economy by providing the opportunity to display women's talent and competence to senior management in order to acquire relevant information through informal networks that can enhance career success. However, these rapid changes are having a severe effect on women as they have to face more significant barriers and need different strategies to overcome the isolation, stereotyping, and performance pressure in order to be successful (Akpinar-Sposito, 2013). McMahon et al.'s (2006) worked on barriers for women is complemented by Adhikary's (2016) study on the importance of the assumption that women are under-represented and experience constraints throughout their careers, which is similar to other cases reported worldwide. Kurgat and Omuya (2011) had focused on cultures that deter women from working and affect them from advancing career-wise, Jakobsh (2012) was more concerned with the unsupportive attitudes of women's family, friends, and co-workers who have adverse effects on women's work and their roles in the society. Hence, existing research has recognised the critical role played by women who stereotype themselves since not all bias come externally, as some women often think that they are better multitaskers, better nurturers, and generally not as severe as men (Mirza \& Jabeen, 2011). Challis (2016) pointed out that it is not possible to identify the cause of low self-esteem since beliefs about one's self over an extended period will likely cause this process to be affected by a range of different things.

The issues have grown in the importance light of the recent increase in the number of women's contribution and women leaders entering the upper echelons of organisations as a long-term solution to the double bind of speaking as people become more accustomed to women's leadership roles (Sandberg \& Grant, 2015). It has been observed that modesty imply for women to be a great leader although most of the leader's positions are held by men (Budworth \& Mann, 2010). On top of that, the society continues to expect leadership to look, act and reacts 
as male while they negatively look, act and reacts when women lead (Sandberg \& Chávez, 2014). A much-debated question is whether a temporary position can help women in gaining confidence or showing the requisite skills and abilities needed to perform successfully in a new role; therefore, it is advisable for women to thoroughly consider a position before accepting it permanently (Fitzpatrick \& Curran, 2014). However, these rapid changes are having a severe effect on women in the society where people's beliefs that the qualities of women might shift to match these new realities, for opportunity structures available to women have to broaden as women occupy new positions and roles (Haines et al., 2016). Watson (2014) identified four ways to cut bias and maximize women potential in the workplace are: 1) To examine the problem through a different lens, 2) Help women not to be pressured against self-promotion, 3) Help women learn how to fail and avoid thinking that they need to be perfect, and 4) Help women to prioritize and not do it all. This paper aims to review past research in the year of 2002 until 2017 into these four barrier syndromes such as the glass ceiling syndrome, tiara syndrome, imposter syndrome, and queen bee syndrome on women leaders in upper-level management.

\section{Glass Ceiling Syndrome}

In this recent years, a few authors have begun to understand the glass ceiling concept are being described as the invisible barrier that blocks women's chances of further promotion or advancement up the corporate ladder. This syndrome has limited the movement of women into prominent positions of leadership (Chek et al., 2011; Jakobsh, 2012; Sandberg, 2013). Several authors have considered the effects of the glass ceiling as a barrier which symbolizes a variety of barriers faced by women who attempt to attain senior positions, and also minorities that seek to improve their employment status in corporations, the government, the education sector and non-profit organizations (Akpinar-Sposito, 2013; Al-Manasra, 2013). Overall, there seems to be some evidence to indicate that this topic is essential to focus on finding the conversational and organisational strategy to improve the work of women in the last two or three decades (Korkmaz, 2016). Adhikary (2016) conducted a study on women who perceive barriers for career progression as a factor of why they have to or could not change their jobs. In recent years, there has been an increasing amount of literature on careers following an apprenticeship which differ from the informal acquisition of skills in some ways. Either those with an apprenticeship qualification are better trained in a particular area thus have higher job retention, and job finding skills or the specificity of training is making them less flexible and can lead to job loss (Adda et al., 2006). To date, previous studies have highlighted factors that are associated with women's commitment and dedication to their work and this factors act as facilitators of women's career advancement besides getting advice from their immediate boss along with the level of education, ability to perform, and seniority (Azmi et al., 2012). However, given all that has been mention so far, one may suppose that the findings on women where career breakages are a continuous process that has affected women from advancing in their careers due to the roles played like women (Bellou, 2011). Several studies on women leadership have identified that gender discrimination is a severe obstacle where inaccurate facts about women are presented such as lacking self-confidence and not being serious enough about their careers in climbing the corporate ladder whereas these misrepresentations often veil women's capacity for leadership (Longman \& Anderson, 2016; Walker \& Aritz, 2015). In a study conducted by Gipson et al. (2017) stated that senior leaders are the most prominent explanations for the leadership gap on gender stereotypes and biases that result in prejudice and discrimination against aspiring women.

\section{Tiara Syndrome}

Previous studies have reported a phenomenon known as 'The Tiara Syndrome' in women who wait to get picked for promotions or raises because they internalise cultural rules about femininity and allow this to guide their behaviours, whether or not those assumptions and biases are even valid (Watson, 2014). It has been argued that women who ask for their rights will look nagging and demanding, which are some of the typical female characteristics in the Tiara Syndrome that are commonly evident in females who lack self-confidence instead of being women who encourage themselves to advance or stand for their rights (Sabra, 2016). Some researchers have reported that women having this syndrome are often reluctant to apply for promotions even though they deserve these promotions and believe that good job performance will naturally lead to rewards (Sandberg, 2013; Fitzpatrick \& Curran, 2014). Thus far, previous studies have shown that tiara syndrome are related to women having a low self-esteem that can stop women from living life and lead to frustration or depression over time that makes it hard to try new things and complete tasks such as applying for a new opportunity or completing a job application (Challis, 2016). Recent evidence suggests that self-esteem level is the conceptualisation of gender within culturally defined roles and responsibilities because awareness and education are critical factors to bring changes in the perception of an individual as the need to value themselves can further elevate their self-esteem level (Nupur \& Mahapatro, 2016). Results from earlier studies demonstrate a strong and consistent association between self-esteem in a person's success and well-being in important life domains (Orth \& Robins, 2014). 
However, higher self-confidence enhances an individual's motivation that causes vested interest in her performance, thus acting as an incentive to build up and maintain her self-esteem (Benabou \& Tirole, 2002; Mostovicz et al., 2009). It has been claimed that the formation of self-esteem implies a lengthy process which is related to personal beliefs about skills, abilities, and social relationships (Revesz, 2016). Together, these studies indicate that women with tiara syndromes are because they are having low self-esteem and have to struggle throughout their career progressions.

\section{Imposter Syndrome}

A considerable amount of literature has been published on the imposter syndrome, and this study is described as a diagnosis or an interpretation that effectively open a gap between the cultural work, projections onto others, and internal sense of self or the recurrent feelings of failing and faking (Bannatyne, 2015; Simmons, 2016). Traditionally, it has been argued that the impostor syndrome is a symptom of a more significant problem that causes women to undervalue their contributions and feel like a fraud where they consistently underestimate themselves (Sandberg, 2013; Vachon, 2014). Recent evidence suggests that an individual who often has the imposter syndrome over-estimates the abilities of others by feeling that this is the only tool they have to meet expectations and underestimates the amount of work for those individuals who have put effort into their success (Parkman, 2016). A study by Sakulku and Alexander (2011) offers probably the most comprehensive empirical analysis on the imposter syndrome where the understanding of the consequences can help an individual who suffers from this syndrome to reduce the imposter fear of depression or anxiety, thus making them able to fulfil their academic or work requirements despite their self-perceived fraudulence. However, individuals who suffer from this phenomenon have intense and secret feelings of fraudulence when facing achievement tasks or challenging situations (Neureiter \& Traut-Mattausch, 2017). Perhaps the most critical findings reflect the fact that women with frequent impostor symptoms tend to seek validation from others, be sensitive to criticism, ruminate about less than perfect performance, and be overly concerned about mistakes (Dudau, 2014). In turn, these lead sufferers to downplay or even hide their achievements and avoid climbing the professional ladder (Fitzpatrick \& Curran, 2014). Up to now, several studies have indicated that imposter syndrome is effected from low self-confidence of women which the manipulation that is relative to a high self-confidence manipulation would result in more negative appraisals of one's self about others and higher levels of paranoia (Alvarado, 2015; Atherton et al., 2016). In a study which was set out to determine self-confidence, Tung and Chapman (2014) found that the opportunity for an individual to accurately assess their social settings leads them to engage in social behaviours deemed acceptable and appealing to peers as well as socially acceptable decisions that are likely to be copied by others. In a follow-up study, Filippin and Paccagnella (2012) found that confidence is a part of the belief that is being adapted as a random variable of individual ability, although it is meaningless to talk about overconfidence as long as the right level of ability is a point estimate. In a study conducted by Preston (2007), stated that people who are confident do not need to show off or impose themselves on others since they have high expectations of themselves and know that their self-worth is independent of their achievements and that they do not always have to be perfect. The evidence presented in this section suggested that clarification of self-confidence is valuable because it improves an individual's motivation to go for a new opportunity and persevere in the pursuit of her goals despite the setbacks and temptations that sometimes test her determination (Benabou \& Tirole, 2002). Collectively, these studies outline a critical role for women who have experienced gender stereotyping since they promote the imposter syndrome symptoms which lead them to become self-fulfilling prophesies (Vachon, 2014). Therefore, it seems that those suffering from this common syndrome are afraid others will find out what they are doing and are obsessed with their perceived weaknesses rather than celebrate their accomplishments.

\section{Queen Bee Syndrome}

Numerous studies have attempted to explain the queen bee syndrome as women who have made it to a leadership role in industries dominated by males while getting rewarded for keeping the other female worker bees down by preventing other women from doing the similar climb (Sandberg, 2013; Vachon, 2014). In 2006, Dobson and Iredale published a paper in which they described women bosses are more likely than men to discriminate against women employees, markdown women's prospects for promotion and assessed women are more controlling than men in their management and leadership style. Ten years later, Zhao and Foo (2016) reported a stereotypical case of queen bee syndrome which is undoubtedly a negative image that obstructs other women's career advancement. Furthermore, the author concluded that if a senior woman leader has a reputation as a queen bee, woman in less senior positions are often advised to avoid working with her as queen bees are seen as selfish, insensitive, and power hungry. It has been conclusively shown that women who perceive their gender as a liability will probably induce them to advance their career through queen-bee behaviours such as 
emphasising their masculine characteristics, expressing gender-stereotypical views of other women, and denying the existence of gender bias (Derks et al., 2011). However, these studies provide valuable insights into the leading theory about Queen Bees who figure that they made it to the top without help and that women in more junior positions can do it too when most women did not break the glass ceiling alone (Krotz, 2016). Recently, these questions have been addressed by researchers in many fields. Half of the studies evaluated have failed to specify whether the queen bee syndrome still exists. Thus we may still expect to find evidence of the queen bee syndrome (Ellemers et al., 2004). Howe-Walsh and Turnbull (2016) claimed that the lack of women in senior positions itself acts as a barrier to more women reaching higher levels within institutions. Therefore, the changes in the position of women in the society suggest that we would find some concurrent changes in stereotypes as well (Haines et al., 2016).

\section{Conclusion}

This study had set out to review in detail available information on four common barrier syndromes such as the glass ceiling syndrome, tiara syndrome, imposter syndrome, and queen bee syndrome. This study has reviewed the effect of these four common syndromes towards women as successful leaders. The past decade has seen that the rapid development of leadership studies on women is that women have to go through the barriers before they become successful. Recent developments in the field of leadership have led to a renewed interest in women breaking the glass ceiling and the multiple strategies that can be taken to overcome the barriers. However, women leaders' determination to be successful by going through all the barriers remains a significant challenge. Current researches on the glass ceiling syndrome, tiara syndrome, imposter syndrome, and queen bee syndrome are still progressing worldwide.

\section{References}

Adda, J., Dustmann, C., Meghir, C., \& Robin, J. (2006). Career Progression and Formal versus On-The-Job Training. Iza Discussion Paper, (2260), 1-57. Retrieved from http://discovery.ucl.ac.uk/40888/

Adhikary, J. R. (2016). Barriers To Career Progression: A Study Of The Perceptions Of Nepali Women Employees. Journal of Business and Management Research, 1(2), 17-32.

Akpinar-Sposito, C. (2013). Career Barriers for Women Executives and the Glass Ceiling Syndrome: The Case Study Comparison between French and Turkish Women Executives. Procedia - Social and Behavioral Sciences, 75, 488-497. https://doi.org/10.1016/j.sbspro.2013.04.053

Al-Manasra, E. A. (2013). What Are The Glass Ceiling Barriers Effects On Women career Progress In Jordan? International Journal of Business and Management, 8(6), 40-47. https://doi.org/10.5539/ijbm.v8n6p40

Alvarado, C. (2015). I'm Not All That: A Look At The Imposter Phenomenon In Intimate Relationships. Masters Thesis, Eastern Washington University.

Atherton, S., Antley, A., Evans, N., Cernis, E., Lister, R., Dunn, G., ... Freeman, D. (2016). Self-Confidence and Paranoia: An Experimental Study using an Immersive Virtual Reality Social Situation. Behavioural and Cognitive Psychotherapy, 44, 56-64.

Azmi, A. G., Syed Ismail, S. H., \& Basir, S. A. (2012). Facilitators of Women's Career Advancement in Public Service: A Study in A Developing Country. International Journal of Social Science and Humanity, $2(1), 5$.

Azmi, I. A. G., Syed Ismail, S. H., \& Basir, S. A. (2014). Muslim Women Career Advancement: A Study of Indonesian Public Service. International Journal of Business and Social Science, 5(2), 168-179.

Bannatyne, A. (2015). When Will My Cover Be Blown? The Experience of Imposter Syndrome in Emerging and Early Career Academics/Educators (2nd ed.). Bond University.

Bellou, V. (2011). Do Women Followers Prefer A Different Leadership Style Than Men? The International Journal of Human Resource Management, 22(13), 2818-2833.

Benabou, R., \& Tirole, J. (2002). Self-Confidence and Personal Motivation. The Quarterly Journal of Economics, $117(3), 871-915$.

Budworth, M.-H., \& Mann, S. L. (2010). Becoming a Leader: The Challenge of Modesty For Women. Journal of Management Development, 29(2), 177-186. https://doi.org/10.1108/02621711011019314

Challis, S. (2016). How to increase your self- esteem (2nd ed.). United Kingdom: Mind.

Chek, I. T., Ismail, S., Mohamad, S., Jusoff, K., Norwani, N. M., \& Khairuddin, M. L. (2011). Gender and Communication Issues in the Malaysian Public Universities. World Applied Sciences Journal, (12), 41-45. 
Derks, B., Van Laar, C., Ellemers, N., \& de Groot, K. (2011). Gender-Bias Primes Elicit Queen-Bee Responses Among Senior Policewomen. Psychological Science, 22(10), 1243-1249. Retrieved from http://journals.sagepub.com/doi/10.1177/0956797611417258

Dobson, R., \& Iredale, W. (2006, December 31). Office Queen Bees Hold Back Women's Careers. Times Newspaper Ltd., pp. 1-2.

Dudau, D. P. (2014). The Relation Between Perfectionism and Impostor Phenomenon. Procedia - Social and Behavioral Sciences, 127, 129-133.

Ellemers, N., Heuvel, H., Gilder, D., Maass, A., \& Bonvini, A. (2004). The Underrepresentation of Women in Science: Differential Commitment or the Queen Bee Syndrome? British Journal of Social Psychology, 43(3), 315-338. https://doi.org/10.1348/0144666042037999

Filippin, A., \& Paccagnella, M. (2012). Family Background, Self-Confidence and Economic Outcomes. Economics of Education Review, 31(5).

Fitzpatrick, T. A., \& Curran, C. R. (2014). Waiting For Your Coronation: A Career-Limiting Trap. Claiming the Corner Office, 32(3), 162-165.

Gipson, A. N., Pfaff, D. L., Mendelsohn, D. B., Catenacci, L. T., \& Burke, W. W. (2017). Women and Leadership: Selection, Development, Leadership Style, and Performance. Journal of Applied Behavioral Science, 53(1), 32-65. https://doi.org/10.1177/0021886316687247

Grenacre, L, Tung, N. M., Chapman, T. (2014). Self-Confidence and the Ability to Influence. Academy of Marketing Studies Journal, 18(2), 169-181.

Haines, E. L., Deaux, K., \& Lofaro, N. (2016). The Times They Are Changing or Are They Not? A Comparison of Gender Stereotypes, 1983-2014. Psychology of Women Quarterly, 40(3), 353-363. https://doi.org/10.1177/0361684316634081

Howe-Walsh, L., \& Turnbull, S. (2016). Barriers To Women Leaders In Academia: Tales From Science And Technology. Studies in Higher Education, 41(3), 415-428. https://doi.org/10.1080/03075079.2014.929102

Jakobsh, D. R. (2012). Barriers to Women's Leadership. Encyclopedia of Leadership, 1-5. https://doi.org/10.1108/eb004111

Korkmaz, H. (2016). Glass Ceiling Syndrome and Women in Top Management: Case of Botswana. In Proceedings of The IRES 26th International Conference (pp. 27-30). Paris, France.

Krotz, J. L. (2016, September). Queen bee syndrome: Do women judge women leaders more harshly? Working Mother.

Kurgat, A., \& Omuya, J. M. (2011). Barriers Towards Career Development Among Women Employees at Workplace: Case Study Kerio Valley Development Authority (KVDA). International Journal of Current Research, 3(11), 97-100.

Longman, K. A., \& Anderson, P. S. (2016). Women in Leadership: The Future of Christian Higher Education. Christian Higher Education, 15(1-2), 24-37.

Mirza, A. M., \& Jabeen, N. (2011). Gender Stereotypes And Women In Management The Case Of Banking Sector Of Pakistan. Journal of South Asian Studies, 26(2), 259-284.

Mostovicz, E. I., Kakabadse, N. K., Kakabadse, A. P., \& Mostovicz, E. I. (2009). A Dynamic Theory of Leadership Development. Leadership \& Organization Development Journal, 30(6). https://doi.org/10.1108/01437730910981935

Neureiter, M., \& Traut-Mattausch, E. (2017). Two Sides of The Career Resources Coin: Career Adaptability Resources and The Impostor Phenomenon. Journal of Vocational Behavior, 98, 56-69. https://doi.org/10.1016/j.jvb.2016.10.002

Nupur, C., \& Mahapatro, M. (2016). Gender Differences in Self Esteem Among Young Adults of Raipur, Uttar Pradesh, India. Austin J Womens Health, 3(1), 1018.

Orth, U., \& Robins, R. W. (2014). The Development of Self-Esteem. Current Directions in Psychological Science, 23(5), 381-387. https://doi.org/10.1177/0963721414547414

Parkman, A. (2016). The Imposter Phenomenon in Higher Education: Incidence and Impact. Journal of Higher Education Theory and Practice, 16(1), 51-60. 
Preston, D. L. (2007). 365 Steps to Self-Confidence (3rd ed.). United Kingdom: How To Books Ltd.

Revesz, G. (2016). Introduction to The Psychology of Self-Esteem. In F. Holloway (Ed.), Self-Esteem: Perspectives, Influences, and Improvement Strategies (1st ed., pp. 1-23). Egypt: Nova Science Publishers, Inc.

Sabra, N. E. (2016). Dare You Rocking It: Contemporary Women and the Trap of The Glass Ceiling in Chick Lit. International Journal of English and Literature, 7(10), 159-166.

Sakulku, J., \& Alexander, J. (2011). The Impostor Phenomenon. International Journal of Behavioral Science, $6(1), 73-92$.

Sandberg, S. (2013). Lean In: Women, Work And The Will To Lead (1st ed.). New York: Vintage Books.

Sandberg, S., \& Chávez, A. M. (2014, November). "Bossy,” the Other B-word. The Saturday Essay, 1-4.

Sandberg, S., \& Grant, A. (2015, January 12). Why Women Stay Quiet at Work. The New York Times, pp. 1-3.

Simmons, D. (2016). Impostor Syndrome, a Reparative History. Engaging Science, Technology, and Society, 2 , 106-127. https://doi.org/10.17351/ests2016.33

Vachon, C. J. (2014). Tiaras, Queen Bees, Imposters and the Board Room: Lean in and Women in Corporate Governance. Journal Of Business \& Technology Law, 9(2), 279-292.

Walker, R. C., \& Aritz, J. (2015). Women Doing Leadership: Leadership Styles and Organizational Culture. International Journal of Business Communication, 52(4), 452-478.

Watson, K. (2014, June). Managing Women and Their Own Unconscious Bias. Orange Grove Consulting.

Zhao, S., \& Foo, M. (2016, September). Queen Bee Syndrome: The Real Reason Women Do Not Promote Women. Center for Creative Leadership, 1-10.

\section{Copyrights}

Copyright for this article is retained by the author(s), with first publication rights granted to the journal.

This is an open-access article distributed under the terms and conditions of the Creative Commons Attribution license (http://creativecommons.org/licenses/by/4.0/). 